\title{
МОТИВАЦІЯ НАЗВ БРИТАНСЬКИХ ТЕЛЕВІЗІЙНИХ ПРОГРАМ
}

У статті розглянуто основні типи мотивації назв британських телевізійних програм. 3'ясовано, що найпродуктивнішою є сутнісна мотивація, тобто найбільш поширені назви, які прямо чи опосередковано відображають зміст, указують на жанр або формат телепередачі. Досліджувані телевізіоніми також мають посесивну, локативну, темпоральну й асоціативну мотивачіі. Символічні назви трапляються досить рідко. Незалежно від типу мотивації, у процесі творення телевізіонімів широко використовують найрізноманітніші стилістичні засоби, щ, мають зробити назву оригінальною, привабливою та легкою для запам'ятовування.

Ключові слова: власна назва, онім, ідеонім, телевізіонім, мотивація.

Zosimova O., Lisna O. Motivation for Naming British Television Programmes. The article deals with motivation for naming British TV programmes.

The topicality of this study is determined by the fact that the research on the derivational structure, semantics and pragmatics of names of TV shows belongs to the important issues of contemporary onomastcis. A comprehensive analysis of names of $T V$ programmes on the material of different languages can give an opportunity to identify distinguishing features of this special type of proper names that have not been thoroughly discussed by linguists yet.

The aim of the research is to identify and describe the main motives for naming British TV shows. The tasks to be solved are as follows: 1) to give a brief description of TV programmes names as a special kind of onyms; 2) to classify the names of British TV shows according to their motivation; 3) to identify the most productive motives.

It has been found that essential motivation (according to M. Torchynskyi's classification) is the most productive one, and the most abundant are names that directly or indirectly convey the idea, describe the genre or format of a TV programme. For example, quite informative onyms are names of many British cooking shows, medical and police realty shows or documentaries. The names of TV programmes in the UK are also represented by possessive (include the name of the host / presenter), locative (indicate the place where the show or documentary is set), temporal (indicate the time when the programme is broadcast), and associative types of motivation (associative names are based on associations with various objects, real people, fictional characters, etc.). Symbolic names that contain regional, national or universal symbols are quite rare.

To make the names of $T V$ shows attractive and memorable, different stylistic devices are widely used, namely: alliteration, rhyming, puns (play on words), antithesis and parallelism, etc.

Key words: proper name, onym, ideonym, name of a television programme, motivation. 


\section{Вступ}

Провідними ресурсами створення і розвитку інформаційного суспільства є засоби масової інформації, зокрема телебачення. Воно не тільки повідомляє про події у світі, але й формує світогляд та уявлення про навколишній світ. Саме через це неможливо не усвідомлювати соціально-культурної значущості телепередач різних жанрів, зважаючи на їхню регулярність виходу в ефір і масовість аудиторії, що значною мірою є сьогодні результатом їх постійної доступності на багатьох онлайн-платформах. Природно, що для того, аби формувати уявлення та здійснювати вплив на глядача, телепрограма має бути популярною й у певний спосіб авторитетною. При цьому важливим чинником популярності телепередач $€$ їхні назви.

Дериваційну структуру, мотивацію та функції назв телепрограм вивчали М. Баган (Баган, 2018), О. Ткачук-Мірошниченко (ТкачукМірошниченко, 2016) та М. Торчинський (Торчинський, 2015), який також найбільшою мірою приділив увагу теоретичному обгрунтуванню лінгвістичного статусу цього різновиду ідеонімів та їх класифікації. Попри певні зрушення у вивченні телевізіонімів, вони досить рідко є об'єктом мовознавчого аналізу, і чимало питань досі потребує детального розгляду. Отже, актуальність теми цього дослідження зумовлена іiі відповідністю напрямам сучасних лінгвістичних студій та необхідністю подальшого докладного вивчення назв телевізійних програм на матеріалі різних мов, зокрема англійської, що дасть можливість визначити специфіку цього особливого класу онімів.

Метою статті $\epsilon$ виявлення та опис основних мотивів номінації у сфері назв британських телевізійних передач. Досягнення цієї мети передбачає розв'язання конкретних завдань: 1) дати стислу характеристику телевізіонімів як специфічного різновиду власних назв; 2) класифікувати назви британських телепрограм за типом мотивації; 3) з'ясувати, які з виокремлених мотиваційних типів $є$ найбільш продуктивними.

Об’єктом дослідження є назви оригінальних програм британського телебачення (List). До нашої вибірки не залучаємо телепередачі закордонного виробництва, а також обмежуємося вивченням суто телевізійних жанрів, а саме: назв ток-, тревел-, реаліті-, кулінарних шоу, музичних, спортивних, політичних дискусійних програм, вікторин та інших ігрових / змагальних шоу, дитячих програм різного формату 
тощо. Не залучаємо до аналізу назви художніх та анімаційних фільмів, а також серіалів, які становлять велику й особливу групу телевізіонімів і потребують окремого дослідження. Як виняток, об’єктом нашої студії є документалістика з огляду на специфіку жанру, а також його популярність на британському телебаченні, що традиційно вважається лідером у виробництві високоякісних документальних фільмів.

\section{Методи дослідження}

Для досягнення поставленої мети були використані такі методи дослідження: аналітично-описовий - для класифікації й опису мотиваційних типів назв британських телевізійних програм; метод словотвірного аналізу - для з'ясування дериваційних особливостей деяких досліджуваних онімів; кількісний аналіз - для визначення ступеня продуктивності різних типів мотивації.

\section{Виклад основного матеріалу}

Назви телевізійних програм (телевізіоніми) розглядаємо як вид пропріальної лексики, що є складником ідеонімів - власних назв нематеріальних об’єктів (Торчинський, 2017: 299), або «денотатів розумової, ідеологічної та художньої сфер людської діяльності» (Торчинський, 2008: 110). Слід зазначити, що цей вид онімів належить до більш широкого класу рекламних імен та характеризується чіткою прагматичною спрямованістю. Телевізіонімам, як правило, притаманні індивідуальність, умотивованість, подекуди словотвірна оригінальність. Саме врахування цих критеріїв допомагає створити назву, яка буде яскравою й вирізнятиме програму на тлі інших однакових телепередач. Щоправда, словотвірна оригінальність деяких сучасних українських телевізіонімів, на думку М. Баган, набуває гіпертрофованого вияву (Баган, 2018: 184), оскільки в гонитві за тим, щоб назва вражала й легко закарбовувалася в пам'яті глядачів, продюсери втрачають почуття міри. Важливою рисою телевізіонімів є семантична ясність: назва має відображати основний зміст телепередачі й бути зрозумілою для аудиторії, за винятком тих випадків, коли автори програми зумисно прагнуть заінтригувати глядача.

Телевізіоніми належать до особливої групи онімної лексики, функційне призначення якої - диференціювати індивідуальні об’єкти, увиразнювати їхню специфіку (Баган, 2018: 183-184). Також слід наголосити на динамічності цього класу онімів. На відміну від 
антропонімів, міфонімів, топонімів і космонімів, які характеризуються відносною стабільністю (Торчинський, 2015: 669), склад назв телевізійних передач постійно оновлюється.

Як відомо, теорія номінації, або ономасіологія, - це наука, яка спирається «на поняття і встановлює, яке позначення, найменування має мова для його називання, звідси - ономасіологія. Її завдання <...> досліджувати, чому мова використовує те або інше слово для позначення того або іншого поняття» (Хмара, 2004: 423). Як важливий об'єкт відображення суспільного світогляду, ономасіологія відкриває широкі можливості для досліджень. Ономасіологія вивчає не тільки можливі варіанти номінації, але й нерозривний зв'язок мови, мислення та суспільства. Для того, щоб процес номінації відбувся, має бути наявним мотиваційний чинник.

Отже, розглянемо мотивацію британських телевізіонімів.

За нашими спостереженнями, найбільшу групу становлять назви, що прямо чи опосередковано вказують на зміст телепередачі, тобто, згідно з класифікацією М. Торчинського, є передусім сутнісними - це переважно трансформовані одиничні апелятиви або словосполучення, зміст яких безпосередньо пов'язаний із тими функціями, які повинен виконувати денотат; саме такі найменування безпосередньо вказують на тип денотата й часто поєднуються з різними його ознаками, утворюючи відповідні комбіновані мотиваційні різновиди (Торчинський, 2008: 467). Зважаючи на зміст та спрямованість назви телевізійної програми, було виділено такі підгрупи сутнісних телевізіонімів:

1. Назви, які вказують на кулінарну тематику: Celebrity MasterChef, Chinese Food Made Easy та I Can Cook. Привертає увагу назва The Naked Chef, що вказує не на відсутність вбрання кухаря, а на його готовність відкрити всі секрети кулінарної майстерності (Wikipedia). Ready! Steady! Cook! - назва кулінарного телешоу, утворена за зразком відомого висловлювання "Ready! Steady! Go!" Деякі назви, зокрема останню, можна вважати прикладами комбінованої мотивації, а саме сутнісно-асоціативної: згідно з класифікацією М. Торчинського, асоціативні оніми виникають за аналогією до інших назв або реалій (Торчинський, 2008: 479).

2. Назви, які вказують на медичну тематику: 24 Hours in A\&E, Hospital 24/7, Your Life in Their Hands та Junior Paramedics. Телевізіонім One Born Every Minute повністю відображає зміст телепередачі. 
Ця телевізійна програма показує шлях, який проходять різні сімейні пари від бажання мати дитину до пологового будинку (Wikipedia).

3. Назви, які вказують на поліцейську тематику: Police, Camera, Action!, Police Interceptors та 24 Hours in Police Custody.

Наступна група сутнісних телевізіонімів - це номінації, які прямо чи опосередковано розкривають жанр телепередачі. Більшість назв цієї групи імпліцитно вказують на жанр. Наприклад, ідеонім Are You Smarter than a 10 Year Old? підказує глядачеві, що це гра, де дорослий, відповідаючи на запитання, повинен довести, що він розумніший за 10-річну дитину. Ask a Family натякає, що змагаються не просто гравці, а члени однієї родини. Схожим принципом номінації керуються творці телепередач Beat the Teacher, Battle of the Brains, Beat the Star, або ж Double Your Money. Значний час телеефіру займають талант-шоу, назва яких у певний спосіб інформує про вид здібностей, у яких змагатимуться учасники. Зокрема, Must Be the Music i Pop Idol зорієнтовані на пошук співаків і музикантів, а Got to Dance, Let's Dance for Comic Relief, Strictly Come Dancing - танцюристів, Dancing on Ice фігуристів (Wikipedia).

Відносно популярними $є$ посесивні телевізіоніми (Торчинський, 2008: 472), утворені від імен ведучих. Такий спосіб номінації є ефективним, адже він дає можливість глядачеві обрати не тільки жанр, але й особу, яку йому приємно бачити на екрані. Одними з найпоширеніших у цій групі $є$ назви кулінарних телепрограм, утворених від імен ведучих - відомих британських кухарів - Гордона Рамзі та Джеймі Олівера, наприклад: Gordon Ramsey: Uncharted, Oliver's Twist та Jamie at Home. Телевізіонім Oliver's Twist водночас $є$ асоціативним, адже для англійців він одразу співвідноситься з назвою відомого роману Ч. Діккенса “Oliver Twist”, і дотепна гра слів одразу впадає в око.

Варто відзначити, що британське телебачення розвінчує міф про звичайні ток-шоу або вечірні шоу із запрошеними зірками, пропонуючи телевізійні програми різноманітної тематики. Ведучою передачі Emergency with Angela Griffin є відома британська актриса Анджела Гріффін, яка подорожує містом разом із бригадою швидкої допомоги (також маємо приклад комбінованої мотивації - сутнісно-посесивної). Dr. Jeff: Rocky Mountain Vet показує роботу відомого британського ветеринара (Wikipedia). Поряд із вузькоспеціалізованими назвами широко функціонують також загальні номінації вечірніх телешоу: The Catherine Tate Show, The Keith Barret Show ra The Jeremy Kyle Show (List). 
Наступна група - це телевізіоніми, що походять від назв географічних об’єктів, тобто, за класифікацією М. Торчинського, є локативними (Торчинський, 2008: 469). Цей вид номінації представлений документальними фільмами та тревел-шоу (травелогами). Особливістю цих телевізіонімів $€$ те, що вони містять назви конкретних країн, материків, океанів тощо. Отже, онім виконує локативну функцію, указуючи на місце дії. Наприклад, Africa, Atlantic: The Wildest Ocean on Earth; British Isles - A Natural History; Wild Caribbean та The Great Rift: Africa's Wild Heart (Wikipedia).

Ще одна група назв має темпоральну мотивацію, тобто вказує на час виходу телевізійної програми в ефір. Зокрема, назва After Dark повідомляє, що телепередача виходить пізно ввечері й піднімає важливі, серйозні питання. Телевізіонім The Late, Late Breakfast Show дещо дезінформує свого глядача, підказуючи, що “пізній сніданок” настає ввечері (Wikipedia).

Окрему групу становлять назви, які є здебільшого суто асоціативними. За нашими спостереженнями, деякі британські асоціативні телевізіоніми, що виникають за аналогією до інших назв або реалій, майже не дають чіткої інформації про суть програми. Зокрема, назва шоу Girl Friday, з одного боку, одразу натякає англійцю або будь-якому освіченому читачеві про П’ятницю - вірного помічника та “компаньйона” Робінзона Крузо з однойменного роману Даніеля Дефо, а суть реаліті-шоу полягала саме в тому, що його героїня провела 9 днів на безлюдному острові в океані (Wikipedia). 3 другого боку, в англійській мові активно функціонує фразеологічна одиниця таn / girl Friday на позначення офісного працівника - відданого асистента / помічниці (секретарки) (Oxford), тому сама тільки назва телепередачі без анонсу з поясненням не розкриває іiі змісту, отже, іiі можна вважати суто асоціативною. Назва телегри Trick or Treat $€$ прямою алюзією на відомий вигук під час святкування Гелловіну (Dictionary). Водночас, хоча асоціація зі святом простежується миттєво, суть програми вона відображає досить опосередковано: якщо учасники гри витягають карту з написом 'Trick', вони мають пройти певне випробування в скрутній ситуації, якщо їм пощастить обрати карту 'Treat', вони отримують певний позитивний досвід, хоча на практиці цей розподіл негативних / позитивних вражень не є таким однозначним для учасників (Wikipedia). 
Цікавим прикладом асоціативної мотивації є назва популярної дитячої програми Blue Peter, що вперше вийшла в ефір у 1958 році, але й досі транслюється на каналі СВВС (ії визнано рекордсменом“довгожителем” серед дитячих телешоу у всьому світі) (Wikipedia). Отже, для англійців Blue Peter - це морський сигнальний прапор (Dictionary), з яким автори програми пов'язали написання назви, логотип шоу, тематичне оформлення локацій тощо, хоча загалом шоу не $є$ суто “морським", а передбачає найрізноманітніші конкурси, інтерв’ю із зірками, поради щодо створення іграшок чи прикрас своїми руками та інші “цікавинки” для дітей.

Певною мірою натякає на зміст телепрограми назва All Our Yesterdays, що розповідала глядачам про минуле Британії з показом документальних кінохронік та студійними коментарями. У щотижневих випусках ішлося про 1930-ті роки, роки Другої світової війни та повоєнний період (Wikipedia). Однак назву програми навряд чи можна вважати сутнісною, оскільки, крім натяку на минуле, жодної іншої інформації про зміст телепередачі вона не надає. Крім того, власне вислів, покладений в основу телевізіоніма, - це алюзія на монолог Макбета з однойменної п’єси В. Шекспіра (акт 5, сцена 5, після смерті леді Макбет), тому асоціації можуть бути досить різними.

Незначною кількістю прикладів серед досліджуваних назв представлені символічні телевізіоніми, мотивація яких «будується на певних конотаціях, пов’язаних зі змістом твірної лексеми, і ці додаткові семантичні відтінки трансформують оніми в символи: індивідуальні, групові, регіональні, загальнонаціональні або всесвітні» (Торчинський, 2008: 478). Згідно з «Оксфордським словником», 'X factor' - це виняткова (специфічна) якість, особлива й така, що є важливою для досягнення успіху і яку важко описати» (Oxford). Саме це значення лексеми стало основою символічної назви мегапопулярного музичного талант-шоу The X Factor, формат якого було створено саме в Британії у 2004 p. (Wikipedia). Яскравою метафоричною номінацією $є$ назва романтичного телешоу Baggage, учасники якого повинні розкривати свої секрети (Wikipedia). Тобто слово baggage означає тут таємниці й життєвий досвід, що людина носить із собою, ніби багаж. На нашу думку, цей телевізіонім можна вважати символічним.

Також до символічних можна віднести назву серії документальних фільмів Cousins, що розповідає про різні види мавп. Слово cousin 
в англійській мові вживають на позначення не лише двоюрідного брата / сестри, але й просто далекого родича, а також людей з інших країн, які в певний спосіб $є$ схожими з людьми у власній країні мовця, чи, зрештою, будь-яких істот або понять, які мають певну схожість (Oxford). Тому автори фільму обрали цю назву як символ близькості людини до мавп - наших найближчих родичів у світі природи.

Варто наголосити, що незалежно від типу мотивації в процесі творення телевізіонімів широко використовують найрізноманітніші стилістичні засоби й прийоми, що мають зробити назву оригінальною, привабливою та легкою для запам'ятовування. Зокрема, застосовують алітерацію (Cash Cab; Feel the Fear, Famous and Fearless), римування (Don't Scare the Hare), гру слів: Art Attack (пор.: heart attack); Desperate Scousewives (від scouse - ліверпульський діалект (Oxford)); Knightmare (від knight - лицар) - дитяча пригодницька програма, де учасники мають пройти квест у ролі середньовічних лицарів (Wikipedia); Odd One In (від вислову odd one out); протиставлення та паралелізм (Big Cook, Little Cook; Big Star's Little Star) тощо (пор.: Zosimova, 2016: 66). У телевізіонімaх також широко використовують фразеологізми: назва телегри Dog Eats Dog походить від ідіоми, що натякає на вкрай важливу ситуацію, у якій потрібно зробити все, щоб досягти успіху, не гребуючи жодними засобами (Cambridge); евфемізми: в основу назви телешоу Blankety Blank (UK) покладено вислів, який уживають для заміни певного грубого слова (Oxford); неформальну лексику (Cleverdicks; Gogglebox).

\section{Висновки}

Британські телевізіоніми вирізняються своєю мотиваційною різноплановістю. Аналіз назв засвідчує, що найпродуктивнішою $€$ сутнісна мотивація, тобто найбільш поширені назви, які прямо чи опосередковано відображають зміст телепередачі. Досліджувані телевізіоніми також мають посесивну, локативну, темпоральну та асоціативну мотивацію. Найменшою мірою представлені символічні назви. Асоціативний чинник найчастіше поєднується з іншими типами мотивації, насамперед сутнісним компонентом, тож чимало телевізіонімів мають комбіновану мотивацію.

Перспективи дослідження вбачаємо у вивченні мотивації назв британських телевізійних передач на більш широкому матеріалі з урахуванням додаткових чинників (загальної спрямованості та цільової 
аудиторії телеканалу, дати виходу програм в ефір тощо), а також порівняльному аналізі британських телевізіонімів з іноземними, зокрема американськими та українськими.

\section{ЛIТЕРАТУРА}

1. Баган, М. П. (2018). Проблема культури онімотворення в сучасному українському телевізійному просторі. Украйнський смисл, 1, 181-193. 2. Ткачук-Мірошниченко, О. Є. (2016). Структурно-мотиваційний та комунікативно-прагматичний аспекти дослідження англомовних назв телепередач (на прикладі телевізійного програмного контенту каналу TLC). Наук. зап. Нац. ун-ту «Острозька академія». Серія «Філологічна», 63, 199-201. 3. Торчинський, М. М. (2017). Власні назви нематеріальних об'єктів: структура, диференційні ознаки, перспективи дослідження. Наук. зап. Терноп. наи. пед. ун-ту. Серія «Мовознавство», 1 (27), 299-303. 4. Торчинський, М. М. (2015). Власні назви телепередач: структура, словотвір, мотивація. Записки з ономастики, 18, 669-683. 5. Торчинський, М. М. (2008). Структура онімного простору украӥнської мови. Хмельницький: Авіст. 6. Хмара, Г. В. (2004). Номінація як об'єкт лінгвістичних досліджень: історія становлення і сучасність. Вісн. Львів. ун-ту, 34, 423-427. 7. Cambridge Dictionary. Узято з https://dictionary.cambridge. org/. 8. Dictionary by Merriam-Webster. Узято з https://www.merriam-webster.com/. 9. List of British television programmes. Wikipedia: The Free Encyclopedia. Узято з https:// en.wikipedia.org/wiki/List_of_British_television_programmes. 10. Oxford Learner's Dictionaries. Узято 3 https://www.oxfordlearnersdictionaries.com/. 11. UK Game Shows. Узято з http://www.ukgameshows.com/. 12. Wikipedia: The Free Encyclopedia. Узято 3 http://en.wikipedia.org. 13. Zosimova, O. V. (2016). Motivation of American Informal Place Names. Наук. зап. Бердян. держ. пед. ун-ту. Серія «Філологічні науки», IX, 61-68.

\section{REFERENCES}

1. Bahan, M. P. (2018). Problema kultury onimotvorennia v suchasnomu ukrainskomu televiziinomu prostori [The problem of the culture of onym formation in contemporary Ukrainian television sphere]. Ukrainskyi smysl - Ukrainian Sense, 1, 181193 [in Ukrainian]. 2. Tkachuk-Miroshnychenko, O. Ye. (2016). Strukturno-motyvatsiinyi ta komunikatyvno-prahmatychnyi aspekty doslidzhennia anhlomovnykh nazv teleperedach (na prykladi televiziinoho prohramnoho kontentu kanalu TLC) [Structural, motivational and communicative-pragmatic aspects of the research on English-language names of TV shows (based on the TV programs broadcast by TLC)]. Nauk. zap. Nats. un-tu "Ostrozka akademiia». Seriia "Filolohichna»-Academic Papers of the National University of Ostroh Academy. Philology Series, 63, 199-201 [in Ukrainian]. 3. Torchynskyi, M. M. (2017). Vlasni nazvy nematerialnykh obiektiv: struktura, dyferentsiini oznaky, perspektyvy doslidzhennia [Proper names of non-material objects: Structure, distinguishing features, prospects for further study]. Nauk. zap. Ternop. nats. ped. un-tu. Seriia «Movoznavstvo»Academic Papers of Ternopil National Pedagogical University. Series «Linguistics», 1 (27), 299-303 [in Ukrainian]. 4. Torchynskyi, M. M. (2015). Vlasni nazvy teleperedach: struktura, slovotvir, motyvatsiia [Proper names of TV programs: Structure, derivation, motivation]. Zapysky z onomastyky - Opera in onomastica, 18, 669-683 [in Ukrainian]. 5. Torchynskyi, M. M. (2008). Struktura onimnoho prostoru ukrainskoi movy [Structure 
of the Onymic Space of the Ukrainian Language]. Khmelnytskyi: Avist [in Ukrainian]. 6. Khmara, H. V. (2004). Nominatsiia yak obiekt linhvistychnykh doslidzhen: istoriia stanovlennia i suchasnist [Nomination as an Object of Linguistic Research: A History of Formation and Modern Times]. Visn. Lviv. un-tu - Lviv University Journal, 34, 423-427 [in Ukrainian]. 7. Cambridge Dictionary. Retrieved from https://dictionary.cambridge.org/ [in English]. 8. Dictionary by Merriam-Webster. Retrieved from https://www.merriamwebster.com/ [in English]. 9. List of British television programmes. Wikipedia: The Free Encyclopedia. Retrieved from https://en.wikipedia.org/wiki/List_of_British_television_ programmes [in English]. 10. Oxford Learner's Dictionaries. Retrieved from https:// www.oxfordlearnersdictionaries.com/ 11. UK Game Shows. Retrieved from http://www. ukgameshows.com/ [in English]. 12. Wikipedia: The Free Encyclopedia. Retrieved from http://en.wikipedia.org [in English]. 13. Zosimova, O. V. (2016). Motivation of American Informal Place Names. Nauk. zap. Berdian. derzh. ped. un-tu. Seriia «Filolohichni nauky»Academic Papers of Berdiansk State Pedagogical University. Series «Philology Series», IX, 61-68.

Зосімова Оксана Віталіївна - кандидат філологічних наук, доцент, доцент кафедри практики англійського усного і писемного мовлення, Харківський національний педагогічний університет імені Г. С. Сковороди; вул. Валентинівська, 2, м. Харків, 61168, Україна.

Tel.: +38-0572-68-43-25;

E-mail: oksanazosimova@ukr.net

http://orcid.org/0000-0002-5446-2222

Zosimova Oksana Vitaliivna - Candidate of Philological Sciences (Ph.D.), Docent, Associate Professor at the Department of Practice of Oral and Written English, H. S. Skovoroda Kharkiv National Pedagogical University; 2 Valentynivska Str., Kharkiv, 61168, Ukraine.

Лісна Олена Іванівна - магістр факультету іноземної філології, Харківський національний педагогічний університет імені Г. С. Сковороди; вул. Валентинівська, 2, м. Харків, 61168, Україна.

Tel.: +38-066-464-47-37;

E-mail: lesnaya.lena@gmail.com

https://orcid.org/0000-0001-9691-3688

Lisna Olena Ivanivna - Master Student at the Faculty of Foreign Philology, H. S. Skovoroda Kharkiv National Pedagogical University; 2 Valentynivska Str., Kharkiv, 61168, Ukraine.

Надійшла до редакції 13 вересня 2021 року

\section{CITATION}

ДСТУ 8302:2015: Зосімова О. В., Лісна О. І. Мотивація назв британських телевізійних програм. Лінгвістичні дослідження: зб. наук. пр. Харк. нац. пед. ун-ту імені Г. С. Сковороди. Харків, 2021. Вип. 55. С. 12-21. DOI: https://doi.org/10.34142/ 23127546.2021.55.02

APA: Зосімова, О. В., \& Лісна, О. І. (2021). Мотивація назв британських телевізійних програм. Лінгвістичні дослідження, 55, 12-21. DOI: https://doi.org/10.34142/ 23127546.2021.55.02 